\title{
Rho-Associated Protein Kinase 1
}

National Cancer Institute

\section{Source}

National Cancer Institute. Rho-Associated Protein Kinase 1. NCI Thesaurus. Code C29877.

Rho-associated protein kinase 1 (1354 aa, $158 \mathrm{kDa}$ ) is encoded by the human ROCK1 gene. This protein is involved in both the propagation of Rho signaling and protein phosphorylation. 